\title{
Induced changes in the growth of four plant species due to lead toxicity
}

\author{
Adriana A. Batista ${ }^{1}$, Jorge A. G. Santos ${ }^{2}$, Marcela R. Bomfim³, \\ Flávia M. Moreira ${ }^{4}$, Emylly F. Leal ${ }^{2} \&$ Joseane N. da Conceição $^{2}$ \\ ${ }^{1}$ Universidade Federal Rural de Pernambuco/Programa de Pós-Graduação em Ciência do Solo. Recife, PE. E-mail: drialves86@yahoo.com.br \\ ${ }^{2}$ Universidade Federal do Recôncavo da Bahia/Programa de Pós-Graduação em Solos e Qualidade de Ecossistemas. Cruz das Almas, BA. E-mail: \\ gonzaga.jorgeas@gmail.com; emylly_figueredo@yahoo.com.br; joseanenascimento13@gmail.com \\ ${ }^{3}$ Universidade Federal do Recôncavo da Bahia/Centro de Ciências Agrárias, Ambientais e Biológicas. Cruz das Almas, BA. E-mail: reboucas.marcela@gmail.com \\ (Corresponding author) \\ ${ }^{4}$ Universidade Estadual do Sudoeste da Bahia/Programa de Pós-Graduação em Agronomia. Vitória da Conquista, BA. E-mail: fmmoreira_ef@yahoo.com.br
}

\section{Key words:}

trace metals

remediation

phytostabilization

\begin{abstract}
A B S T R A C T
Lead is a toxic metal that affects plant growth and the ecosystem. This study evaluated the lead $(\mathrm{Pb})$ bioaccumulation potential of vetiver (Vetiveria zizanioides L.), sunflower (Helianthus annuus L.), elephant ear (Alocasia macrorrhiza) and 'embaúba' (Cecropia sp.). The plant species were tested in a 50\% nutrient solution - Hoagland and Arnon, constantly aerated, containing five Pb concentrations: 0, 50, 100, 200 and $400 \mathrm{mg} \mathrm{L}^{-1}$ ). The treatments were arranged in a completely randomized design in a 4 x 5 factorial scheme, with four replicates. The $\mathrm{Pb}$ contents in the plants increased linearly with the $\mathrm{Pb}$ exposure concentration. Vetiver was the species with the highest $\mathrm{Pb}$ content in the shoots $(260.24$ $\mathrm{mg} \mathrm{kg}^{-1}$ ) and sunflower, in the roots (44925.20 mg kg-1). Pb concentration of up to 100 and $50.9 \mathrm{mg} \mathrm{L}^{-1}$ stimulated sunflower biomass and root length, respectively. None of the evaluated species met the hyperaccumulator criterion; however, sunflower and vetiver have the potential to be tested for phytostabilization purposes.
\end{abstract}

\section{Palavras-chave:}

metal traço

remediação

fitoestabilização

\section{Mudanças induzidas no crescimento de quatro espécies vegetais pela toxicidade de chumbo}

\section{R E S U M O}

O chumbo é um metal tóxico que impacta o crescimento de plantas e os ecossistemas. Avaliou-se o potencial de bioacumulação de $\mathrm{Pb}$ nas espécies vetiver (Vetiveria zizanioides L.), girassol (Helianthus annuus L.), orelha de elefante (Alocasia macrorrhiza) e embaúba (Cecropia sp.) em cinco concentrações de $\mathrm{Pb}\left(0,50,100,200\right.$ e $\left.400 \mathrm{mg} \mathrm{L}^{-1}\right)$ em solução nutritiva Hoagland e Arnon, meia força, constantemente aerada. Os tratamentos foram dispostos em delineamento experimental inteiramente casualizado em esquema fatorial 4 x 5, com 4 repetições. Durante 21 dias, a concentração do metal nas plantas aumentou linearmente com a concentração de exposição ao $\mathrm{Pb}$. O vetiver foi a espécie com maior concentração de $\mathrm{Pb}$ na parte aérea $\left(260,24 \mathrm{mg} \mathrm{kg}^{-1}\right)$ e girassol na raiz $\left(44.925,20 \mathrm{mg} \mathrm{kg}^{-1}\right)$. A biomassa e o comprimento radicular de girassol foram estimulados até a concentração de 100 e 50,9 $\mathrm{mg} \mathrm{L}^{-1}$ de $\mathrm{Pb}$, respectivamente. Nenhuma das espécies atendeu aos critérios de hiperacumulação; entretanto, girassol e vetiver devem ser testados como espécies fitoestabilizadoras. 


\section{INTRODUCTION}

Among the 275 priority substances of the USA, based on frequency, toxicity and exposure potential, lead $(\mathrm{Pb})$ is considered as the second most toxic, according to the Agency for Toxic Substances and Disease Registry (ATSDR, 2015). According to this environmental agency, $\mathrm{Pb}$ concentrations between 10 and $40 \mu \mathrm{g} \mathrm{dL}^{-1}$ in the blood cause adverse effects on human health (neurological, hematologic and renal systems). Despite the effects caused on soils, water, atmosphere and living organisms, $\mathrm{Pb}$ continues to be widely used in industrial processes.

$\mathrm{Pb}$-contaminated areas represent danger to living organisms and must be remediated for human benefit and agroecological sustainability. The municipality of Santo Amaro, Bahia, is the example of $\mathrm{Pb}$ contamination from galena processing activities. The soil of this area has been contaminated by the direct disposal of residues and deposition of particles emitted by the chimney, in a wide range of $\mathrm{Pb}$ concentration, between 2.03 and $12,678 \mathrm{mg} \mathrm{kg}^{-1}$, at the depth of 0-5 cm (Asevedo, 2012), evidencing the need for adopting remediation methods.

Phytoextraction has been indicated as a low-cost alternative to extract the metal present in the soil and water (Bhargava et al., 2012), if the concentration in the soil allows plant growth. This technique is based on the assumption of the existence of plants that are tolerant to the metal. Toxic effects have been observed on plants with $\mathrm{Pb}$ concentrations between 30 and 300 $\mathrm{mg} \mathrm{kg}^{-1}$ (Shikhova, 2012); this wide range of toxicity reveals different levels of tolerance, combined with the fact that $\mathrm{Pb}$ does not have a known biological function (Ali et al., 2013).

The selection of phytoextraction plants aims to identify species that are tolerant to the contaminant, which must exhibit characteristics such as fast growth and sufficient biomass production to accumulate greater contents of metals, especially in the shoots (Paz-Alberto \& Sigua, 2013). Plants intended for phytostabilization must be limited to the accumulation of the metal in the roots (Magalhães et al., 2011).

Hydroponics has been used to select plants and determine the efficiency of absorption and tolerance to metals in potentially phytoremediation species (Espinoza-Quiñones et al., 2013), but studies under greenhouse and field conditions are necessary to validate the obtained results. This study compared the absorption, potential of distribution, effect on root system and level of tolerance to $\mathrm{Pb}$ of four plant species under hydroponic conditions.

\section{Material ANd Methods}

The experiment was carried out in a greenhouse of the Soils and Quality of Ecosystems Graduate Program of the Federal University of Recôncavo of Bahia, municipality of Cruz das Almas, BA, Brazil.

The study evaluated the capacity of four plant species: vetiver (Vetiveria zizanioides L.), sunflower (Helianthus annuus L.), elephant ear (Alocasia macrorrhiza) and 'embaúba' (Cecropia sp.) to absorb, tolerate and distribute $\mathrm{Pb}$ in the different plant parts when exposed to the $\mathrm{Pb}$ concentrations of $0,50,100,200$ and $400 \mathrm{mg} \mathrm{L}^{-1}$, applied in the form of $\mathrm{Pb}$ acetate $(\mathrm{AL})\left(\mathrm{Pb}\left(\mathrm{C}_{2} \mathrm{H}_{3} \mathrm{O}_{2}\right) \cdot 3 \mathrm{H}_{2} \mathrm{O}\right)$, referred to as $\mathrm{C}_{0}, \mathrm{C}_{50}, \mathrm{C}_{100}$,
$\mathrm{C}_{200}$ and $\mathrm{C}_{400}$, respectively. The treatments were arranged in completely randomized design in a $4 \times 5$ factorial scheme, with four replicates, and the experimental unit consisted of one plant per pot (capacity for $3 \mathrm{~L}$ ), with $2.5 \mathrm{~L}$ of nutrient solution ( $\mathrm{pH} 5.0 \pm 0.2$ ).

The seedlings were acclimated for 10 days in nutrient solution of Hoagland \& Arnon (1950), 50\% ionic force, without $\mathrm{Pb}\left(\mathrm{C}_{0}\right)$. After this period, the nutrient solution was replaced and added of $\mathrm{Pb}$ acetate at the concentrations indicated in the treatments. One control treatment, without $\mathrm{Pb}$ $\left(\mathrm{C}_{0}\right)$, was also evaluated. Twenty-one days after the beginning of the exposure to $\mathrm{Pb}$, the plants were harvested and washed in running water, in a solution of $0.1 \mathrm{M} \mathrm{HCl}$ and distilled water. Then, the plants were divided into shoots and roots, and their biomasses were determined after drying at $65^{\circ} \mathrm{C}$ for $72 \mathrm{~h}$, in a forced-air oven.

Roots were washed using a fine mesh sieve and air-dried; then, they were digitalized using a scanner (Hp G4050, 100 dpi resolution, shades of gray and bitmap format) and processed in the application GSRoot (Guddanti \& Chambers, 1993), to obtain the root length for the diameter classes of $<0.1 ; 0.1-0.25$; $0.25-0.5 ; 0.5-0.75 ; 0.75-1.0 ; 1.0-2.0$ and $>2.0 \mathrm{~mm}$.

After drying, the plant material was weighed on a semianalytical scale (Marte, AC200, $210 \mathrm{~g}$ x $0.001 \mathrm{~g}$ ) and ground in a TE 650 Wiley-type mill (1-mm-mesh screen) for digestion. In summary, $0.500 \mathrm{~g}$ of the biomass were weighed and mixed with $5 \mathrm{~mL}$ of $65 \% \mathrm{HNO}_{3}$, which was cold-digested for $16 \mathrm{~h}$. Then, temperature was gradually increased to $80^{\circ} \mathrm{C}$ and, after successive additions of $30 \% \mathrm{H}_{2} \mathrm{O}_{2}$ until the volume of $3 \mathrm{~mL}$, the temperature was increased to $140{ }^{\circ} \mathrm{C}$, the extracts were filtered and the volume completed to $25 \mathrm{~mL}$ with $2 \% \mathrm{HNO}_{3}$. The $\mathrm{Pb}$ contents were determined through atomic absorption (Varian AA 240F, Varian Instruments, Australia) and the bioaccumulation (BF) and translocation (TF) factors were calculated through Eqs. 1 and 2.

$$
\begin{gathered}
\mathrm{BF}=\frac{\mathrm{Pb} \text { content in the shoots or roots }}{\mathrm{Pb} \text { concentration in the nutrient solution }} \\
\mathrm{TF}=\frac{\mathrm{Pb} \text { content in the shoots }}{\mathrm{Pb} \text { content in the roots }}
\end{gathered}
$$

According to the ability to accumulate $\mathrm{Pb}$, the species were classified as accumulators $(\mathrm{BF}>1)$; indicators $(\mathrm{BF}=1)$ and excluders $(\mathrm{BF}<1)$ (Accioly \& Siqueira, 2000), while those with $\mathrm{TF}>1$ were classified as phytoextractors.

The data was statistically analyzed using the statistical package Sisvar 5.3 (Ferreira, 2011). For the attributes with significant interaction $(\mathrm{p}<0.05)$, the species was fixed to evaluate the behavior of the attributes at the different $\mathrm{Pb}$ concentrations using regression equation, with minimum determination coefficient of $65 \%$.

\section{Results AND Discussion}

After 21 days of exposure to $\mathrm{Pb}$, its contents in shoot and roots of the species increased linearly $(\mathrm{p}<0.01)$ with the concentration (C) in the solution (Table 1). The low $\mathrm{Pb}$ contents found at 
Table $1 . \mathrm{Pb}$ contents in the shoots and roots $\left(\mathrm{mg} \mathrm{kg}^{-1}\right)$ of the species, in response to the increasing Pb concentrations $\left(\mathrm{mg} \mathrm{L}^{-1}\right)$ in the nutrient solution

\begin{tabular}{|c|c|c|c|c|c|c|c|c|}
\hline \multirow{2}{*}{$\mathrm{Pb}$} & \multicolumn{2}{|c|}{ Vetiver } & \multicolumn{2}{|c|}{ Sunflower } & \multicolumn{2}{|c|}{ Elephant ear } & \multicolumn{2}{|c|}{ 'Embaúba' } \\
\hline & Shoots & Roots & Shoots & Roots & Shoots & Roots & Shoots & Roots \\
\hline 0 & 7.54 & 338.21 & 6.12 & 60.23 & 8.85 & 41.27 & 9.92 & 83.89 \\
\hline 50 & 23.36 & $2,239.14$ & 27.24 & $11,314.80$ & 13.95 & $1,683.93$ & 22.64 & $2,758.86$ \\
\hline 100 & 36.04 & $3,550.77$ & 29.99 & $16,704.24$ & 19.95 & $2,276.96$ & 35.96 & $2,410.7 \mathrm{c}$ \\
\hline 200 & 110.77 & $4,356.25$ & 39.03 & $26,974.38$ & 35.79 & $4,063.89$ & 55.95 & $6,617.15$ \\
\hline 400 & 260.24 & $13,790.44$ & 91.67 & $44,925.17$ & 78.36 & $7,265.32$ & - & - \\
\hline Intercept & 10.40 & 35.71 & 9.21 & $4,089.34$ & 4.89 & 469.63 & 11.01 & 312.61 \\
\hline LC & $0.65^{* *}$ & $32.13^{\star \star}$ & 0.20 ** & $106.04^{* *}$ & 0.18 ** & $17.31 * \star$ & $0.23^{* *}$ & $30.34^{* *}$ \\
\hline $\mathrm{R}^{2}$ & 0.98 & 0.96 & 0.95 & 0.97 & 0.98 & 0.99 & 0.99 & 0.92 \\
\hline
\end{tabular}

** Significant at 0.01 probability level by $\mathrm{F}$ test. Intercept, linear coefficient (LC) and correlation coefficient $\left(\mathrm{R}^{2}\right)$ of the regression equation

concentration zero $\left(\mathrm{C}_{0}\right)$ must be attributed to the impurities of the reagents used. The $\mathrm{Pb}$ content in the shoots at $\mathrm{C}_{400}$ followed a decreasing order: vetiver $\left(260.24 \mathrm{mg} \mathrm{kg}^{-1}\right)>$ sunflower $(91.67 \mathrm{mg}$ $\left.\mathrm{kg}^{-1}\right)>$ elephant ear $\left(78.36 \mathrm{mg} \mathrm{kg}^{-1}\right)$. Since the $\mathrm{Pb}$ content in shoot biomass was below $1000 \mathrm{mg} \mathrm{kg}^{-1}$, none of the species could be classified as hyperaccumulator of $\mathrm{Pb}$ (Accioly \& Siqueira, 2000). The decreasing order of $\mathrm{Pb}$ contents in the roots was different from that obtained in the shoots: sunflower $\left(44,925.17 \mathrm{mg} \mathrm{kg}^{-1}\right)$ $>$ vetiver $\left(13,790.44 \mathrm{mg} \mathrm{kg}^{-1}\right)>$ elephant ear $\left(7,265.32 \mathrm{mg} \mathrm{kg}^{-1}\right)$. The 'embaúba' at $\mathrm{C}_{400}$ did not produce sufficient biomass for the determination of the $\mathrm{Pb}$ contents.

The $\mathrm{Pb}$ content in the root of sunflower at $\mathrm{C}_{400}$ was three times higher than that of vetiver (Table 1). The efficiency of vetiver to concentrate $\mathrm{Pb}$ was reported by Pidatala et al. (2016), due to its high growth rate, increasing the absorption of pollutants (Sharma et al., 2016).

The highest $\mathrm{Pb}$ contents in the roots of the evaluated species were similar to those found by Nascimento et al. (2014), who studied $\mathrm{Pb}$ accumulation in forage species in contaminated soils. The accumulation of $\mathrm{Pb}$ in the roots has been attributed to its low mobility in the plant, high affinity for the negative charges of the cell wall and to the physiological barriers of Casparian strips, which restrict its access to the xylem, reducing the translocation (Zhivotovsky et al., 2011).

The $\mathrm{Pb}$ bioaccumulation factor in the shoots of the different species varied from 0.179 ('elephant ear') to 0.651 (vetiver). At all evaluated concentrations, except $C_{50}$, vetiver was the species with highest $\mathrm{Pb}$ bioaccumulation in the shoots (Table 2). 'Embaúba' $\left(C_{100}\right)$ and elephant ear $\left(C_{400}\right)$ were the treatments with lowest $\mathrm{Pb}$ bioaccumulation in the shoot tissue.

The preferential concentration of $\mathrm{Pb}$ in the roots of the plants resulted in higher $\mathrm{BF}$ in the roots, compared with the shoots (Table 2). Sunflower was the species with highest BF values in the roots, which varied from $112.31\left(\mathrm{C}_{400}\right)$ to 226.30 $\left(\mathrm{C}_{50}\right)$. These values were 3 to 5 times higher than those obtained for vetiver; 6 to 7 times higher than those for elephant ear and around 4 times higher than those for 'embaúba'.
All evaluated species showed $\mathrm{TF}<1$, which confirms the low ability to translocate $\mathrm{Pb}$ from roots to shoots (Table 2), a desirable factor for phytostabilization species. Evaluating two species of vetiver (Vetiveria zizanioides and Vetiveria nemoralis), Aksorn \& Chitsombonn (2013) identified that both can effectively act as phytostabilizators for $\mathrm{Pb}$, due to the high contents of the metal in the roots, with values of $\mathrm{TF}<1$. The results of this study show that, among the evaluated species and despite the $\mathrm{TF}<1$, vetiver was the most efficient in the translocation of $\mathrm{Pb}$, followed by elephant ear and 'embaúba', at all evaluated concentrations.

The exposure of the species to $\mathrm{Pb}$ negatively influenced the shoot and root biomass production of vetiver, elephant ear and 'embaúba'. This effect increased with the $\mathrm{Pb}$ exposure concentration (Table 3), except for sunflower.

In sunflower, the exposure to $\mathrm{Pb}$ concentrations of up to $100 \mathrm{mg} \mathrm{L}^{-1}$ stimulated biomass production and, for higher concentrations, there was a reduction in biomass production (Table 3). Senth et al. (2011) also observed increase in shoot biomass (6\%) and root biomass (13\%) of sunflower when exposed to a $\mathrm{Pb}$ concentration $\left(20 \mu \mathrm{M}=4.1 \mathrm{mg} \mathrm{L}^{-1}\right)$ in hydroponic system. With a concentration approximately 25 times higher than that of the present study, shoot and root biomasses in sunflower were 22.80 and $30.12 \%$, respectively, higher than that reported by Seth et al. (2011).

The shoot biomasses of vetiver, elephant ear and 'embaúba', in the control treatment $\left(\mathrm{C}_{0}\right)$, were higher in the presence of any $\mathrm{Pb}$ concentration (Table 3 ). At $\mathrm{C}_{400}$, shoot biomass was $90.71 \%$ ('embaúba') to $81.05 \%$ (elephant ear) lower in relation to the biomass in the control treatment. $\mathrm{Pb}$ also limited root biomass production, in lower intensity than in the shoots, varying from $62.17 \%$ (elephant ear) to $85.24 \%$ (sunflower) in relation to the control. The smaller effect of $\mathrm{Pb}$ on the biomass of elephant ear can be attributed to the lower $\mathrm{Pb}$ contents in its shoots and roots.

The limitation of plant growth by the presence of $\mathrm{Pb}$, reducing biomass, has been attributed to the negative effect

Table 2. Bioaccumulation factor (BF) in shoot and root biomass of the species and translocation factor (TF) of roots, in response to the $\mathrm{Pb}$ concentrations

\begin{tabular}{|c|c|c|c|c|c|c|c|c|c|c|c|c|}
\hline \multirow{3}{*}{$\begin{array}{c}\mathrm{Pb} \\
\mathrm{mg} \mathrm{L}^{-1}\end{array}$} & \multicolumn{3}{|c|}{ Vetiver } & \multicolumn{3}{|c|}{ Sunflower } & \multicolumn{3}{|c|}{ Elephant ear } & \multicolumn{3}{|c|}{ 'Embaúba' } \\
\hline & \multicolumn{2}{|c|}{$\mathrm{BF}$} & \multirow{2}{*}{$\begin{array}{c}\text { TF } \\
\text { Roots }\end{array}$} & \multicolumn{2}{|c|}{ BF } & \multirow{2}{*}{$\begin{array}{c}\text { TF } \\
\text { Roots }\end{array}$} & \multicolumn{2}{|c|}{$\mathrm{BF}$} & \multirow{2}{*}{$\begin{array}{c}\text { TF } \\
\text { Roots }\end{array}$} & \multicolumn{2}{|c|}{$\mathrm{BF}$} & \multirow{2}{*}{$\begin{array}{c}\text { TF } \\
\text { Roots }\end{array}$} \\
\hline & Shoots & Roots & & Shoots & Roots & & Shoots & Roots & & Shoots & Roots & \\
\hline 50 & 0.467 & 44.783 & 0.011 & 0.545 & 226.296 & 0.002 & 0.279 & 33.679 & 0.008 & 0.455 & 55.117 & 0.009 \\
\hline 100 & 0.360 & 35.508 & 0.010 & 0.300 & 167.042 & 0.002 & 0.200 & 22.770 & 0.009 & 0.360 & 24.108 & 0.012 \\
\hline 200 & 0.554 & 21.781 & 0.026 & 0.195 & 134.872 & 0.001 & 0.179 & 20.319 & 0.009 & 0.280 & 33.086 & 0.006 \\
\hline 400 & 0.651 & 34.476 & 0.019 & 0.229 & 112.313 & 0.002 & 0.197 & 18.163 & 0.011 & - & - & - \\
\hline CV (\%) & 16.84 & 28.47 & 22.46 & 15.40 & 16.99 & 61.69 & 19.89 & 14.14 & 191.39 & 21.24 & 21.39 & 24.68 \\
\hline
\end{tabular}


Table 3. Shoot and root biomass production $\left(\mathrm{g} \mathrm{pot}^{-1}\right)$ of the species, in response to the increasing $\mathrm{Pb}$ concentrations in the nutrient solution

\begin{tabular}{|c|c|c|c|c|c|c|c|c|}
\hline \multirow{2}{*}{$\begin{array}{c}\mathrm{Pb} \\
\mathrm{mg} \mathrm{L}^{-1}\end{array}$} & \multicolumn{2}{|c|}{ Vetiver } & \multicolumn{2}{|c|}{ Sunflower } & \multicolumn{2}{|c|}{ Elephant ear } & \multicolumn{2}{|c|}{ 'Embaúba' } \\
\hline & Shoots & Roots & Shoots & Roots & Shoots & Roots & Shoots & Roots \\
\hline 0 & 12.31 & 3.19 & 15.79 & 3.32 & 12.40 & 6.74 & 4.52 & 1.17 \\
\hline 50 & 7.92 & 2.40 & 18.01 & 3.35 & 9.63 & 5.63 & 3.33 & 0.93 \\
\hline 100 & 5.81 & 1.86 & 19.39 & 4.32 & 10.16 & 8.13 & 2.17 & 0.42 \\
\hline 200 & 3.26 & 1.61 & 12.70 & 2.42 & 4.96 & 3.84 & 1.03 & 0.51 \\
\hline 400 & 1.70 & 0.82 & 1.83 & 0.49 & 2.35 & 2.55 & 0.42 & 0.22 \\
\hline Intercept & 9.71 & 7.11 & 17.01 & 3.49 & 11.64 & 2.77 & 3.74 & 0.96 \\
\hline LC & $-2.34 \times 10^{-2 \star *}$ & $-1.15 \times 10^{-2 \star *}$ & - & - & $-2.5 \times 10^{-2 \star \star}$ & $-5.3 \times 10^{-3 * \star}$ & $-9.6 \times 10^{-3 * *}$ & $-2.1 \times 10^{-3 * *}$ \\
\hline $\mathrm{QC}$ & - & - & $-1 \times 10^{-4 \star \star}$ & $-3 \times 10^{-5 \star \star}$ & - & - & - & - \\
\hline $\mathrm{R}^{2}$ & 0.79 & 0.67 & 0.95 & 0.87 & 0.92 & 0.88 & 0.83 & 0.72 \\
\hline
\end{tabular}

** Significant at 0.01 probability level by $F$ test. Intercept, linear coefficient (LC), quadratic coefficient $(\mathrm{QC})$ and correlation coefficient $\left(\mathrm{R}^{2}\right)$ of the regression equation

on spindle organization during mitosis, compromising cell division (Kozhevnikova et al., 2009) and to the deficiency in the absorption of macroelements (Lamhamdi et al., 2013) caused by the lower volume of roots.

In response to the exposure to $\mathrm{Pb}$, plants can alter the root system architecture (volume, diameter and length) through the stimulus or inhibition of roots (Fahr et al., 2013). In the present study, the root length of the species linearly decreased with the increase in $\mathrm{Pb}$ concentration in the nutrient solution (Table 4), except for sunflower, in which the root system length quadratically decreased with the increase of $\mathrm{Pb}$ concentration. The highest estimated value of root length occurred at the $\mathrm{Pb}$ concentration of $50.9 \mathrm{mg} \mathrm{L}^{-1}$ (Table 4).

The root length of vetiver, elephant ear and 'embaúba' was limited by $17.44,21.22$ and $6.49 \mathrm{~cm} \mathrm{mg}^{-1}$ of $\mathrm{Pb}$ in the solution, respectively, compared with $\mathrm{C}_{0}$ (Table 4 ). The root length of vetiver at the $\mathrm{Pb}$ concentration of $400 \mathrm{mg} \mathrm{L}^{-1}$ was $45.5,61.3$ and $87.8 \%$ in comparison to sunflower, elephant ear and 'embaúba', respectively (Table 4). Pereira et al. (2013) attributed the reduction in the initial growth of lettuce roots to the phytotoxic effect of $\mathrm{Pb}$ on the cell division of root apical meristems, to the increase in chromosomic abnormalities and to the anatomic modifications of the roots.

The greatest proportion of roots of the species occurred in the diameter range from 0.10 to $0.50 \mathrm{~mm}$ (Figure 1A, 1B, 1C and $1 \mathrm{D}$ ). The exposure of the plant species to $\mathrm{Pb}$ limited root growth in all diameter ranges (Figures 1A, 1B, 1C and 1D).

Length reduction and the elongation of finer roots seem to be the most affected by $\mathrm{Pb}$, which results in the decrease in the capacity of the plants to absorb water and nutrients and in biomass production (Castro et al., 2009).

Table 4. Root length $(\mathrm{cm})$ of the species in response to the increasing $\mathrm{Pb}$ concentrations in the nutrient solution

\begin{tabular}{lcccc}
\hline \multicolumn{1}{c}{$\begin{array}{c}\mathrm{Pb} \\
\mathbf{m g ~ L}^{-1}\end{array}$} & Vetiver & Sunflower & Elephant ear & 'Embaúba' \\
0 & $8,462.9$ & $4,588.8$ & $8,959.0$ & $3,222.7$ \\
100 & $6,122.5$ & $5,864.0$ & $5,621.6$ & 917.0 \\
200 & $5,184.9$ & $3,517.7$ & $3,658.8$ & $1,232.1$ \\
400 & $1,265.5$ & 688.9 & 489.4 & 152.8 \\
Red. (\%) & 85 & 85 & 95 & 95 \\
Intercept & $8,310.6$ & $4,935.9$ & $8,623.8$ & $2,516.3$ \\
LC & $-17.44^{\star *}$ &. & $-21.22^{\star *}$ & $-6.49^{\star *}$ \\
QC &. & $-0.0364^{\star \star}$ &. &. \\
$\mathrm{R}^{2}$ & 0.99 & 0.90 & 0.98 & 0.72 \\
\hline
\end{tabular}

** Significant at 0.01 probability level by $\mathrm{F}$ test. Intercept, linear coefficient (LC), quadratic coefficient $(\mathrm{QC})$ and correlation coefficient $\left(\mathrm{R}^{2}\right)$ of the regression equation

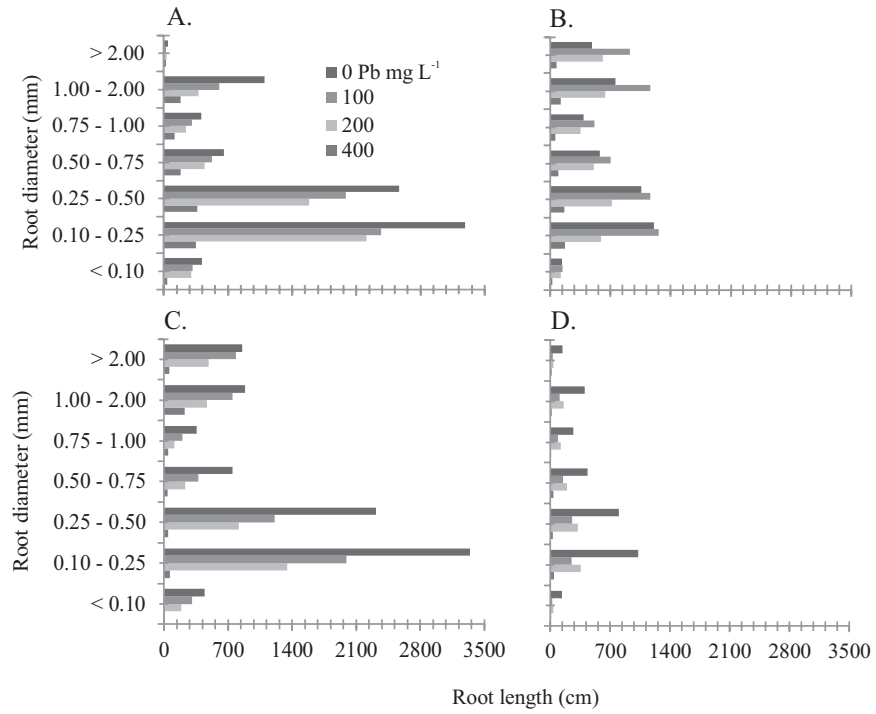

Figure 1. Influence of $\mathrm{Pb}$ concentrations on root length per root diameter, for vetiver (A), sunflower (B), elephant ear (C) and 'embaúba' (D)

The critical limit of $\mathrm{Pb}$ varies from $0.6-28 \mathrm{mg} \mathrm{kg}^{-1}$ (Hodson, 2012) to $30 \mathrm{mg} \mathrm{kg}^{-1}$ (Kabata-Pendias \& Pendias, 2001), tending to accumulate preferentially in the root tissues. In the present study, the tolerance of the plants to $\mathrm{Pb}$ was analyzed based on the $\mathrm{Pb}$ concentration in the solution capable of resulting in 30 $\mathrm{mg} \mathrm{kg}^{-1}$ of $\mathrm{Pb}$ in shoot biomass. Based on this concentration, the effects on shoot and root biomass production and root length of the species were evaluated (Table 5).

The $\mathrm{Pb}$ content of $30 \mathrm{mg} \mathrm{kg}^{-1}$ in shoot biomass was obtained when the $\mathrm{Pb}$ concentration in the solution was of $62 \mathrm{mg} \mathrm{L}^{-1}$ (vetiver) to $149 \mathrm{mg} \mathrm{L}^{-1}$ ('embaúba'). The efficiency of vetiver $\left(62 \mathrm{mg} \mathrm{L}^{-1}\right)$ to bioaccumulate $\mathrm{Pb}$ in the shoots, to achieve 30 $\mathrm{mg} \mathrm{Pb} \mathrm{kg}{ }^{-1}$ in the biomass, was approximately 2.3 and 2.4 times higher than those of elephant ear $\left(142 \mathrm{mg} \mathrm{L}^{-1}\right)$ and 'embaúba' (149 $\mathrm{mg} \mathrm{L}^{-1}$ ), respectively. The $\mathrm{Pb}$ accumulation of $30 \mathrm{mg} \mathrm{kg}^{-1}$ at a lower concentration, observed in vetiver, contributes to

Table 5. Alteration in the biomass and root length of the species when the $\mathrm{Pb}$ concentration in the hydroponic solution results in $30 \mathrm{mg} \mathrm{kg}^{-1}$ of $\mathrm{Pb}$ in the shoots

\begin{tabular}{lcccc}
\hline \multirow{2}{*}{ Species } & $\mathbf{P b}$ & \multicolumn{2}{c}{ Biomass } & Root length \\
\cline { 3 - 4 } & $\left(\mathbf{m g ~ L}^{-1}\right)$ & Shoots & Roots & (cm) \\
Vetiver & 62 & $-15 \%$ & $-12 \%$ & $-13 \%$ \\
Sunflower & 105 & $+3 \%$ & $-1 \%$ & $0 \%$ \\
Elephant ear & 142 & $-30 \%$ & $-23 \%$ & $-35 \%$ \\
'Embaúba' & 149 & $-65 \%$ & $-59 \%$ & $-62 \%$ \\
\hline
\end{tabular}


a smaller effect on shoot $(-15 \%)$ and root $(-12 \%)$ biomass production and root length $(-13 \%)$, in comparison to elephant ear and 'embaúba'.

Although vetiver exhibited capacity to accumulate approximately $40 \%$ more $\mathrm{Pb}$ than sunflower (Table 2), the latter was more tolerant to the $\mathrm{Pb}$ concentration, as evidenced by the effect on shoot biomass (increase of 3\%), root biomass (reduction of 1\%) and root length (no effect) compared with the control. Seth et al. (2011) report that sunflower, for producing proteins that combat stress, is a tolerant species at low concentrations and short periods of exposure to $\mathrm{Pb}$.

\section{Conclusions}

1. Vetiver showed higher capacity to concentrate $\mathrm{Pb}$ in the shoots and sunflower in the roots, compared with 'embaúba' and elephant ear.

2. The evaluated species showed characteristics of phytostabilizators $(\mathrm{TF}<1)$.

3. In general, $\mathrm{Pb}$ reduced the biomass production of the plants, especially of 'embaúba'.

4. $\mathrm{Pb}$ negatively interfered with the biomass production of the species, except sunflower, up to the concentrations of 100 $\mathrm{mg} \mathrm{L}^{-1}$ of $\mathrm{Pb}$ for the shoots and $50.9 \mathrm{mg} \mathrm{L}^{-1}$ of $\mathrm{Pb}$ for the roots.

5. The species vetiver, sunflower and elephant ear are the ones with highest potential to be tested under field conditions.

\section{ACKNOWLEDgments}

The authors thank the National Council for Scientific and Technological Development (CNPq) (Protocol 561889/20104) and the Coordination for the Improvement of Higher Education Personnel (CAPES) for the financial support.

\section{Literature Cited}

Accioly, A. M. A.; Siqueira, J. O. Contaminação química e biorremediação do solo. In: Novais, R. F.; Alvarez, V.; Schaefer, C. E. G. R. Tópicos em ciência do solo. Viçosa: Sociedade Brasileira de Ciência do Solo, 2000. p.299-351.

Aksorn, E.; Chitsomboon, B. Bioaccumulation of heavy metal uptake by two different Vetiver grass (Vetiveria zizanioides and Vetiveria nemoralis) species. African Journal Agricultural Research, v.8, p.3166-3177, 2013. http://dx.doi.org/10.5897/AJAR12.2066

Ali, H.; Khan, E.; Sajad, M. A. Phytoremediation of heavy metals concepts and applications. Chemosphere, v.91, p.869-881, 2013. http://dx.doi.org/10.1016/j.chemosphere.2013.01.075

Asevedo, L. P. Mapeamento geoquímico de solos contaminados por metais (Pb, Zn, As e Cu), Santo Amaro da Purificação, Bahia. Cruz das Almas: UFRB, 2012. 92p. Dissertação Mestrado

ATSDR - Agency for Toxic Substances and Disease Control. CERCL priority list of hazardous substances, 2015. ATSDR. <http://www. atsdr.cdc.gov/spl/>. 25 Abr. 2016.

Bhargava, A.; Carmona, F. F.; Bhargava, M.; Srivastava, S. Approaches for enhanced phytoextraction of heavy metals. Journal of Environmental Management, v.105, p.103-120, 2012. https://doi. org/10.1016/j.jenvman.2012.04.002

Castro, E. M.; Pereira, F. J.; Paiva, R. Histologia vegetal: Estrutura e função de órgãos vegetativos. 1.ed. Lavras: UFLA, 2009. 234p.
Espinoza-Quiñones, F. R.; Módenes, A. N.; Oliveira, A. P.; Trigueros, D. E. G. Influence of lead-doped hydroponic medium on the adsorption/bioaccumulation processes of lead and phosphorus in roots and leaves of the aquatic macrophyte Eicchornia crassipes. Journal of Environmental Management, v.130, p.199-206, 2013. http://dx.doi.org/10.1016 / j.jenvman.2013.09.012.

Fahr, M.; Laplaze, L.; Bendaou, N.; Hocher, V.; Mzibri, M. E.; Bogusz, D.; Smouni, A. Effect of lead on root growth. Frontiers in Plant Science, v.4, p.1-7, 2013. http://dx.doi.org/10.3389/ fpls.2013.00175

Ferreira, D. F. Sisvar: A computer statistical analysis system. Ciência e Agrotecnologia, v.35, p.1039-1042, 2011. http://dx.doi. org/10.1590/S1413-70542011000600001

Guddanti, S.; Chambers, J. L. GSRoot automated root length measurement program, version 5.00; user's manual. Louisiana: Louisiana State University, 1993. 40p.

Hoagland, D. R.; Arnon, D. I. The water culture method for growing plants without soils. Berkeley: California Agricultural Experimental Station, 1950. 32p. Circular Técnica, 347

Hodson, M. J. Metal toxicity and tolerance in plants. Biochemical Society, v.34, p.28-32, 2012.

Kabata-Pendias, A.; Pendias, H. Trace elements in soils and plants. Boca Raton: CRC Press LLC, 2001. 413p.

Kozhevnikova, A. D.; Seregin, I. V.; Bystrova, E. I.; Belyaeva, A. I.; Kataeva, M. N.; Ivanov, V. B. The effects of lead, nickel, and strontium nitrates on cell division and elongation in maize roots. Russian Journal of Plant Physiology, v.56, p.242-250, 2009. http:// dx.doi.org/10.1134/S1021443709020137

Lamhamdi, M.; Galiou, O. E.; Bakrim, A.; Nóvoa-Muñoz, J. C.; AriasEstévez, M.; Aarab, A.; Lafont, R. Effect of lead stress on mineral content and growth of wheat (Triticum aestivum) and spinach (Spinacia oleracea) seedlings. Saudi Journal of Biological Sciences, v.20, p.29-36, 2013. http://dx.doi.org/10.1016/j.sjbs.2012.09.001

Magalhães, M. O. L.; Amaral Sobrinho, N. M. B. A.; Santos, F. S.; Mazur, N. Potencial de duas espécies de eucalipto na fitoestabilização de solo contaminado com zinco. Revista Ciência Agronômica, v.42, p.805-812, 2011. http://dx.doi.org/10.1590/ S1806-66902011000300029

Nascimento, S. S.; Silva, E. B.; Alleoni, L. R. F.; Grazziotti, P. H.; Fonseca, F. G.; Nardis, B. O. Availability and accumulation of lead for forage grasses in contaminated soil. Journal of Soil Science and Plant Nutrition, v.14, p.783-802, 2014. http://dx.doi.org/10.4067/ S0718-95162014005000063

Paz-Alberto, A. M.; Sigua, G. C. Phytoremediation: A green technology to remove environmental pollutants. American Journal of Climate Change, v.2, p.71-86, 2013. http://dx.doi. org/10.4236/ajcc.2013.21008

Pereira, M. P.; Pereira, J. F.; Rodrigues, L. C. de A.; Barbosa, S.; Castro, E. M. Fitotoxidade do chumbo na germinação e crescimento inicial de alface em função da anatomia radicular e ciclo celular. Revista Agro@mbiente, v.7, p.36-43, 2013.

Pidatala, V. R.; Li, K.; Sarkar, D.; Ramakrishna, W.; Datta, R. Identification of biochemical pathways associated Paz-Alberto, A. M.; Sigua, G. C. Phytoremediation: A green technology to remove with lead tolerance and detoxification in Chrysopogon zizanioides L. Nash (Vetiver) by metabolic profiling. Environmental Science Technology, v.50, p.2530-2537, 2016. http://dx.doi.org/10.1021/ acs.est.5b04725 
Seth, C. S.; Misra, V.; Singh, R. R.; Zolla, L. EDTA-enhanced lead phytoremediation in sunflower (Helianthus annuus L.) hydroponic culture. Plant and Soil, v.347, p.231-242, 2011. http://dx.doi. org/10.1007/s11104-011-0841-8

Sharma, H. Phytoremediation of lead using Brassica juncea and Vetiveria zizanioides. International Journal of Life Sciences Research, v.4, p.91-96, 2016.
Shikhova, N. S. Some regularities in the accumulation of lead in urban plants (by example of Vladivostok). Contemporary Problems of Ecology, v.5, p.285-294, 2012. http://dx.doi.org/10.1134/S1995425512020126

Zhivotovsky, O. P.; Kuzovkina, J. A.; Schulthess, C. P.; Morris, T.; Pettinelli, D.; Ge, M. Hydroponic screening of willows (Salix L.) for lead tolerance and accumulation. International Journal of Phytoremediation, v.13, p.75-94, 2011. http://dx.doi.org/10.1080/15226511003671361 